\title{
Tegumentary leishmaniasis outbreak in Bella Vista City, Corrientes, Argentina during 2003
}

\author{
Oscar Daniel Salomón ${ }^{+}$, Sergio Sosa-Estani, Karina Ramos*, \\ Pablo Wenceslao Orellano**, Gustavo Sanguesa** , Gustavo Fernández*, \\ Angel Sinagra***, Guillermo Rapasciolli****
}

Centro Nacional de Diagnóstico e Investigación en Endemo-epidemias, Av. Paseo Colón 568, Buenos Aires, Argentina *Ministerio de Salud Pública Provincia de Corrientes, Corrientes, Argentina **Ministerio de Salud y Ambiente, Buenos Aires, Argentina

***Instituto Nacional de Parasitología, Buenos Aires, Argentina ****Hospital de Bella Vista, Bella Vista, Argentina

Bella Vista City, Corrientes, Argentina, reported an epidemic outbreak of tegumentary leishmaniasis during 2003. The mean age of the 31 cases was $25.0 \pm 13.7$ years old, with a sex ratio male:female 1.8, and without mucosal involvement. They clustered in two contiguous neighbourhoods, $96 \%$ in the periurban border and $4 \%$ in the peripheral outskirts. The transmission peak was estimated to have occurred during April 2003. Four species (3608 sand flies) were captured in nine sites: Lutzomyia neivai (90.1\%), Lu. pessoai (8.9\%), Lu. migonei (0.8 \%), and Brumptomyia avellari ( $0.2 \%)$. The outskirts/rural capture ratio of Lu. neivai was up to 3, and the outskirts/periurban up to 200. Therefore, the 'urban' transmission in this southernmost known focus is still an ecotone-border associated risk. The changes in human distribution or activities, patches of the secondary vegetation, periurban streams, rainfall of the previous year, and river period floods could all contribute to 'urban' outbreaks in the region. Tegumentary leishmaniasis risk should be assessed for any project that involves changes in land use throughout an endemic area.

Key words: leishmaniasis - Lutzomyia neivai - urbanization - ecoepidemiology - Argentina

Tegumentary leishmaniasis (TL) is endemic in area of Northern Argentina that includes nine political provinces and three bio-regions: the 'Yungas' and 'Paranaense' subtropical forests, and the xeric 'Chaco'. Although TL was identified in Argentina almost a century ago, the first recorded outbreak took place in 1984-1987 in the 'Yungas' region, and this was found to be due to Leishmania braziliensis (Sosa Estani et al. 2000, Segura et al. 2000). After this outbreak, the relative increased incidence of TL both children and females suggested a transmission shift from the forest to peridomestic habitats (Sosa Estani et al. 2001, Sosa Estani \& Salomon 2002). In addition, since the early 1980s the re-emergence of TL has been reported for many countries in the region, and urban transmission was proposed by many other investigators (Mott et al. 1990, Desjeux 2001, Campbell-Lendrum et al. 2001, Bejarano et al. 2002, Leonardo \& Rebêlo 2004, Lemos \& Lima 2005).

Lutzomyia intermedia sensu lato, currently termed $\mathrm{Lu}$. neivai (Marcondes 1996), is widely distributed in the province of Corrientes. This species of Lutzomyia was first recorded in Corrientes City in 1926 and again in 1997-2000 (Bejarano \& Duret 1950, Borda et al. 2002), it was also reported in Santo Tomé, Colonia Pellegrini, and Apipé Grande (San Antonio) during 1951 (Duret 1952), in Santa Tecla, Ituzaingó, Villa Olivari and Ita-Ibaté (Spinelli et al.

${ }^{+}$Corresponding author and member of "Carrera del Investigador Científico", Conicet. E-mail:danielsalomon@hotmail.com

Received 12 May 2006

Accepted 14 September 2006
1999, Salomón et al. 2002) during 1993-1998, and in Bella Vista in 1998 (Borda et al. 1998b). Other phlebotomine species also found in the province of Corrientes include Lu. cortelezzii, Lu. migonei, Lu. pessoai, Lu. shannoni, Lu. fischeri, Brumptomyia guimaraesi, and Br. avellari, the former four species were recorded in Corrientes City (Borda et al. 2002), the last seven were recorded in Santa Tecla and the last species was found in Ituzaingó (Spinelli et al. 1999, Salomón et al. 2002) (Fig. 1)

The average incidence of TL in the province of Corrientes, in the 'Paranaense' northeastern region was 2.2, 6.8 , and $11.7 \mathrm{cases} / \mathrm{year}$ for the whole province in the periods 1955-1974, 1975-1994, and 1995-2004 respectively, according to the records of the National Surveillance System and the Dermatologic Dispensary of Corrientes.

Bella Vista City, on the Paraná river shore, according to the Dermatologic Dispensary had two TL cases in 1988, one in 1991, and six in 1998. However during 2003 an outbreak took place in the City, the first recorded for the province, with suspected urban transmission. It was the southernmost known epidemic focus, and one of the scarce epidemics located in the eastern region of Argentina. Thus, this study was conducted in order to define the distribution of vectors and cases, and the risk factors for TL infection in this area. The results characterize the risk distribution of TL infection in time and space, and are discussed in the frame of the TL urbanization hypotheses and the appropriate strategies of surveillance and control.

\section{MATERIALS AND METHODS}

Study area - Bella Vista: Bella Vista City (28 $31^{\prime}$ LS, $\left.59^{\circ} 02^{\prime} \mathrm{LW}\right)$, Bella Vista department, province of Corrientes, 


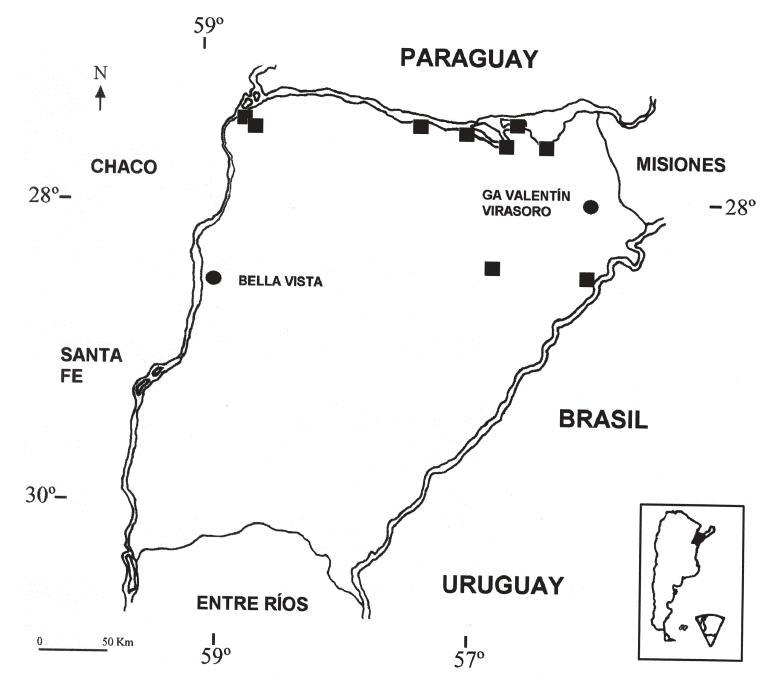

Fig. 1: province of Corrientes, records of phlebotomine in previous reports (squares), Bella Vista where the captures of this study were performed, and GA Valentín Virasoro with captures reported in the discussion (dots).

$140 \mathrm{~km}$ south of Corrientes City. The city is located $32 \mathrm{~m}$ above the Parana river and $66 \mathrm{~m}$ above sea level, in front of the Ramsar site 'Jaakanigás'. The climate is subtropical-tropical without a dry season, although $60 \%$ of the precipitation falls in summer and autumn. The annual variation of temperature is small with a mean temperature of $20^{\circ} \mathrm{C}$. Bella Vista is close to the isohyetal line of $1100 \mathrm{~mm}$, and the relative humidity throughout the year was found to be an average of $71 \%$. The area belongs to the bioregion 'Chaco oriental', in transition to the 'Paranaenese' region (Cabrera 1976). Still water pools are extensively dispersed and occasionally discharge water into the Parana river. The river shore alternates between gallery forests, pioneer woods in overflowed banks, Butia yatay palm forests, and seasonally flooded 'carrizales' (Carnevali 1994). The 'carrizales' are dense herbaceous patches of Panicum grumosum and $P$. rivulare up to $5 \mathrm{~m}$ height, that keep the soil saturated with water all the year round. This study was performed in 'Florida', a periurban neighbourhood of Bella Vista on the border of the city, and in 'Epam', a contiguous peripheral neighbourhood with lower density of houses, outside the urban edge (Fig. 2).

Epidemiological studies - Descriptive and matched case-control studies were conducted, the matched casecontrol studies was designed to define risk factors to have $\mathrm{TL}$ in the area with epicentre in Bella Vista. TL case definition: a person with skin ulcerations consistent with TL and positive parasite confirmation performed on a smear of the scrapings. Control definition: a person without skin ulcerations or scars consistent with TL. Acceptable age differences between cases and controls were \pm 3 years for cases aged $\geq 10$ years, \pm 2 years for cases aged 6-9 years, \pm 1 year for cases aged 1-5 years, and the cases of $<12$ months old were paired with $<12$ months old con- trols. Two controls were randomly selected among the city blocks or area surrounding the residence of each case (two TL cases had only one control). After the informed consent, both cases and controls were examined by a physician, and a questionnaire was performed asking about regular habits, work and spare time activities, household and peridomestic features, wild and domestic animals occurrence, and surrounding landscape description. The probable date of infection was assumed to be 21 days prior to the self-reported beginning of the skin ulceration (Sosa Estani \& Salomon 2002). Fisher's exact or $\chi^{2}$ tests were performed on proportional data, the difference between means by normal distribution with ANOVA test, and Wilcoxon test in the non-parametric analyses. Barlett's test was used to analyse the homogeneity of the data to be contrasted. Statistical significance was assumed with a value of $P<0.05$. The Odds Ratio (OR) was taken as a risk estimator with a confidence interval of $95 \%$ level of significance. The variables related with habits and household factors (domestic and peridomestic) were ordered and analysed with EpiInfo software for Windows (3.2.2. DCD version)

Entomological study - Bella Vista: light minitraps CDC like were settled from 20.00 to $8.00 \mathrm{~h}$ in nine sites simultaneously for three consecutive nights, between October 14th and 17th 2003 (minimal temperature $19^{\circ} \mathrm{C}$ ). Sites (Fig. 2) - A: Epam peripheral neighbourhood (PN); A.1: PN extradomestic: $28^{\circ} 29^{\prime} 13^{\prime \prime} \mathrm{LS}, 59^{\circ} 01^{\prime} 57^{\prime}$ 'LW, $70 \mathrm{~m}$ from the house with a case, in secondary vegetation-banana trees ecotone, $1 \mathrm{~km}$ from Florida neighbourhood; A.2: PN peridomestic: $5 \mathrm{~m}$ from the house; A.3: PN shore:

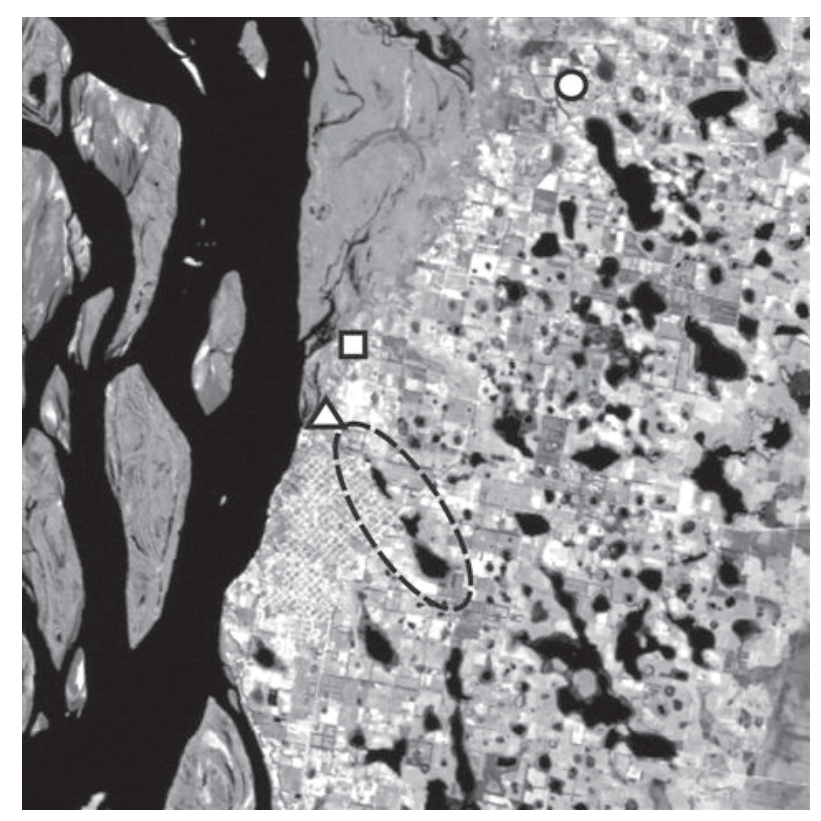

Fig. 2: Landsat 7 TM image from 4/8/2003, Bella Vista, province of Corrientes. Phlebotomine capture rural station (circle), 'Epam' peripheral neighbourhood ecotone site (square), 'Florida' periruban marginal station (triangle). The dot-lined ellipse includes the natural still water pools that drain on the water stream in the edge of the periruban neighbourhood. 
$28^{\circ} 29^{\prime} 21^{\prime \prime} \mathrm{LS}, 59^{\circ} 02^{\prime} 07^{\prime \prime} \mathrm{LW}$, 'carrizal' in clay alluvial land used after the seasonal overflowing of the river to make bricks (work related risk); B: Florida periurban neighbourhood (UN) in the house of cases; B.1: UN peridomestic 1: $28^{\circ} 29^{\prime} 42^{\prime \prime} \mathrm{LS}, 59^{\circ} 02^{\prime} 19^{\prime \prime} \mathrm{LW}$, family farm contiguous to Epam neighbourhood; B.2: UN peridomestic 2: $28^{\circ} 29^{\prime} 44^{\prime \prime} \mathrm{LS}, 59^{\circ} 02^{\prime} 21^{\prime \prime} \mathrm{LW}$, on the shore of a water stream; B.3: UN peridomestic $3: 28^{\circ} 21^{\prime} 50^{\prime \prime} \mathrm{LS}, 59^{\circ} 02^{\prime} 12^{\prime \prime} \mathrm{LW}$, on an vegetated alley; C: R: $28^{\circ} 27^{\prime} 02^{\prime} \mathrm{LS}, 59^{\circ} 00^{\prime} 03^{\prime \prime} \mathrm{LW}$, rural house with cases during 1998, $6 \mathrm{~km}$ from Florida; C.1: R extradomestic: secondary vegetation $100 \mathrm{~m}$ from the house; C.2: R peridomestic: $15 \mathrm{~m}$ from the house in a chicken dwelling; D: Farm, 28 $29^{\prime} 45^{\prime \prime}$ LS, 59 $02^{\prime} 25^{\prime \prime} \mathrm{LW}$, 'Alto del gallero' extensive area of fruit trees mainly citrus and strawberry cultures (risk site according to the community perception). All the phlebotomine were kept dry until they were treated with phenol-lactic acid, and identified according to the keys of Young and Duncan (1994), and Marcondes modifications (1996). Fisher's exact test or $\chi^{2}$ statistical tests were performed, and the results were assumed to be significant when they had associated probabilities of $P<0.05$.

Weather data were provided by the experimental agriculture station INTA Bella Vista, the river height data by the local navy station of the 'Prefectura Naval Argentina' at Bella Vista Port, and the satellite images by the aerospatial national agency CONAE. Six Landsat 7 ETM images were used from the study area (Path/Row 226/80), from April 2001, January, March, May, and December 2002, and April 2003. The images were georeferenced using the satellite ephemerides and the Nearest-Neighbour Method. The areas covered with water were estimated based on band 5 (mid-infrared), the pixels with values of the digital numbers (DN) between 0 and 22 were assumed as covered with water.

\section{RESULTS}

There were found 31 cases in Bella Vista during October 2003 according to the case definition. The age distribution and localization of the lesions are shown in Table I. The male:female ratio was 1.8 but the age distribution did not differ significantly between genders. All the cases had skin lesions, whereas no mucosal involvement was observed. The median period of ulcer evolution up to the diagnosis was 90.0 days, range 15-240 days. All the cases healed after the standard chemotherapy (pentavalent antimonials $20 \mathrm{mg} / \mathrm{kg} /$ day). The residence of the cases was $96 \%$ in the periurban neighbourhood Florida, and the remaining $4 \%$ in the peripheric and contiguous neighbourhood Epam. The time distribution of cases, according to the probable date of infection (Fig. 3), suggests a transmission peak in April 2003, ending in July 2003. Twenty five cases were included in the case-control study, 6 of them were under 15 years old. The case distribution by age, lesion location, and occupation is shown in Table I.

Seventy-three questionnaires were obtained ( 25 cases and 48 controls). The sex distribution and mean age between cases and controls did not differ significantly. The frequency of exposure among cases and controls was significantly different in relation to questions about "to work in the Carrizal", and "to have a house-water stream $<500$ m". However, only "to have cats in the house" was a protective factor according to the paired analysis (Table II).

In Bella Vista 3608 phlebotomine of four species were captured: Lu. neivai (90.1\%), Lu. pessoai $(8.9 \%), L u$. migonei $(0.8 \%)$, and Br. avellari (0.2\%) (Table III). The proportion of species different from $\mathrm{Lu}$. neivai captured in the outskirts habitats (periurban and peripheral) was $0.2 \%$ while in the rural sites it was $26.7 \%$, mainly $L u$. pessoai (24.3\%). The Lu. neivai captured either of each

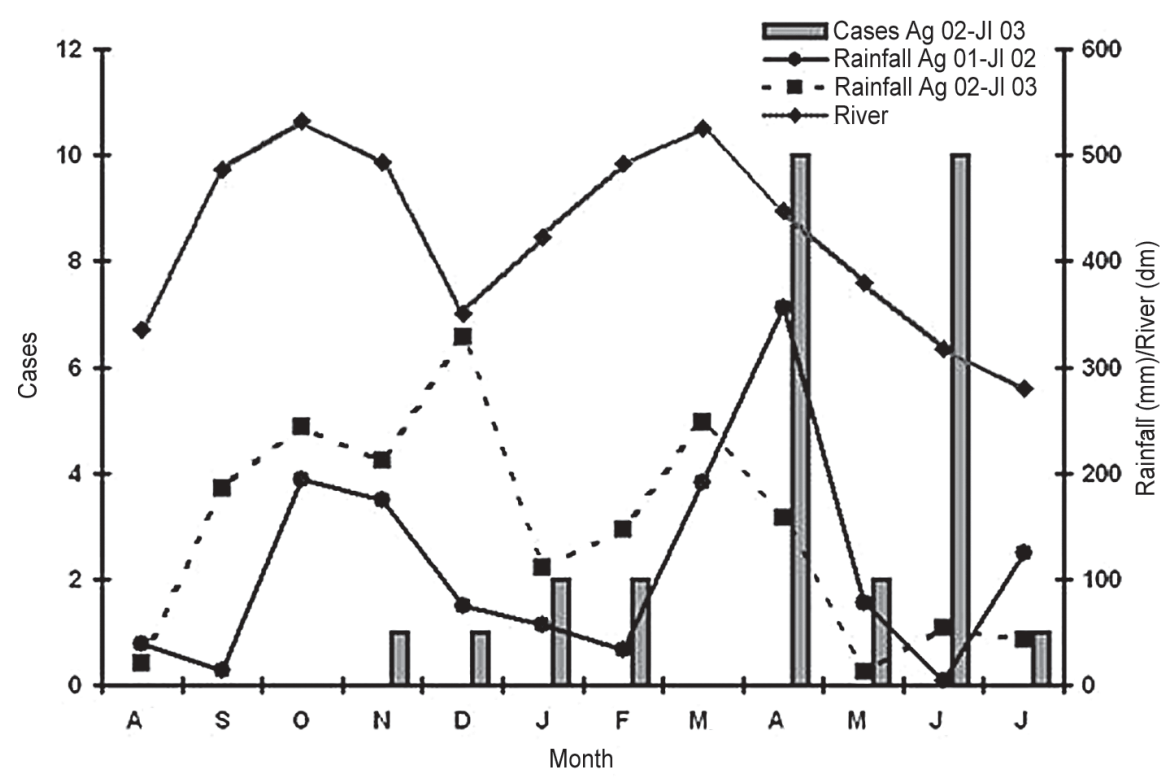

Fig. 3: cases of tegumentary leishmaniasis in Bella Vista, province of Corrientes by month according to the probable date of infection from August 2002 to July 2002. Bella Vista cumulative rainfall records (mm) by month from August 2001 to July 2002, and August 2002 to July 2003. Maximum height of the river (m), Bella Vista Port, from August 2002 to July 2003. 
TABLE I

Age distribution, localization of lesions, and occupation of cases with tegumentary leishmaniasis. Bella Vista, province of Corrientes, Argentina, 2003

\begin{tabular}{lc}
\hline & $\mathrm{N}(\%)$ \\
Age group & $31(100)$ \\
\hline $1-9$ years old & $2(6.5)$ \\
10-19 years old & $9(29.0)$ \\
20-29 years old & $11(35.5)$ \\
$30-39$ years old & $4(12.9)$ \\
$40-49$ years old & $2(6.5)$ \\
50-59 years old & $3(9.7)$ \\
Localization of lesions & $31(100)$ \\
Legs and feet & $13(41.9)$ \\
Arms and hands & $8(25.8)$ \\
Trunk & $3(9.7)$ \\
Head/neck & $3(9.7)$ \\
Multiple lesions & $4(12.9)$ \\
Occupation & $19(100)$ \\
Brick-maker & $4(21.1)$ \\
Farmer & $2(10.5)$ \\
House-wife & $3(15.8)$ \\
Handicrafting & $2(10.5)$ \\
Without occupation & $2(10.5)$ \\
Others (mason, traveler, greengrocer, etc.) & $5(26.3)$ \\
Without data & $1(5.3)$ \\
\hline Agedistrbution and &
\end{tabular}

Age distribution and localization of lesions total $\mathrm{N}=31$ reported cases; occupation total $\mathrm{N}=19$ cases older than 14 years old included in the case-control study.

sex or both together in the ecotone of the peripheral neighbourhood were 2-3 times that of the rural site, and up to 200 times that of the periurban traps. The proportion of females was similar between peridomestic and extradomestic captures of the same capture station, but differed significantly among stations, decreasing as the human intervention in the environment increased: rural $>$ peripheral neighbourhood $>$ periurban neighbourhood. The proportion of $L u$. neivai gravid females captured was similar in the three peridomestic sites, but the difference of the ratio extra/peridomestic was significant between stations from 0.35 in the peripheral neighbourhood to 3.51 in the rural landscape $(P<0.05)$ (Table III).

The monthly data of mean and minimal temperature, sunshine, and relative humidity of the years 2001, 2002, 2003, and 1950-1990 average did not differ significantly (data not shown). However, the 2002 rainfall showed a different pattern mainly during April (average 1950-1990: $139.5 \mathrm{~mm}, 2001: 136.2 \mathrm{~mm}, 2002: 355.7 \mathrm{~mm}, 2003: 158.0 \mathrm{~mm}$ ), one year before the peak of cases according to the probable date of infection (Fig. 3). The height of the Parana river at Bella Vista Port during 2003 was significantly higher than the records of 2002, with a peak in March (maximum/ minimum 2002:3.45/2.80 m, 2003: 5.25/4.36 mt)(Fig. 3). The average between the maximum-minimum height difference of the river from January to April was also higher in 2003 $(1.13 \pm 0.18 \mathrm{~m})$ than in $2002(0.66 \pm 0.04 \mathrm{~m})$.

Based on the satellite imagery, the area covered by water in close proximity to the cases of Florida neighbourhood (Fig. 2) was computed during the overflowing of the water pools. The flooded area showed an increasing trend between the $4 / 18 / 2001,5 / 23 / 2002$, and $4 / 8 / 2003$ serial images of 359,383 , and $416 \mathrm{~km}^{2}$ estimated respectively. However during the intermediate dates of $1 / 15 / 2002$ and 12/17/2002 the areas were 287 and $320 \mathrm{~km}^{2}$, so the annual range was $96 \mathrm{~km}^{2}$ in both years. In the satellite images no area of deforestation was observed that correlated with the TL epidemic outbreak.

\section{DISCUSSION}

In Bella Vista, province of Corrientes, during AugustOctober 2003, 31 cases of TL were recorded. The physical

TABLE II

Risk and protective factors associated with tegumentary leishmaniasis. Bella Vista, province of Corrientes, Argentina, 2003

\begin{tabular}{|c|c|c|c|c|c|}
\hline Habits & Exposed/Total & $\%$ exposed & $\mathrm{P}$ & ORm (CI 95\%) & $\mathrm{P}$ \\
\hline \multicolumn{6}{|c|}{ To work in the carrizal } \\
\hline Cases & $12 / 24$ & 50.0 & & & \\
\hline Controls & $10 / 44$ & 22.7 & 0.02 & $2.0(0.5-11.4)$ & 0.22 \\
\hline \multicolumn{6}{|c|}{ Household factors } \\
\hline \multicolumn{6}{|c|}{ To have cats in the house } \\
\hline Cases & $7 / 25$ & 28.0 & & & \\
\hline Controls & $20 / 45$ & 44.4 & 0.27 & $0.25(0.1-0.7)$ & 0.003 \\
\hline \multicolumn{6}{|c|}{ Peridomestic factors-distance } \\
\hline \multicolumn{6}{|c|}{ House-water stream $<500 \mathrm{~m}$} \\
\hline Cases & $11 / 25$ & 44.4 & & & \\
\hline Controls & $9 / 47$ & 19.1 & 0.04 & $1.9(0.5-10.8)$ & 0.25 \\
\hline \multicolumn{6}{|c|}{ House-secondary forest $<500$} \\
\hline Cases & $19 / 24$ & 71.2 & & & \\
\hline Controls & $27 / 45$ & 60.0 & 0.17 & $2.2(0.4-21.1)$ & 0.25 \\
\hline \multicolumn{6}{|c|}{ House-high secondary forest $<500 \mathrm{~m}$} \\
\hline Cases & $15 / 25$ & 60.0 & & & \\
\hline Controls & $20 / 48$ & 41.7 & 0.21 & $1.2(0.5-5.7)$ & 0.30 \\
\hline
\end{tabular}

P: P value; ORm: matched Odds Ratio; CI: confidence interval. 
TABLE III

Phlebotomine captures with CDC light minitrap, Bella Vista, province of Corrientes, Argentina, October 14 to 172003

\begin{tabular}{|c|c|c|c|c|c|c|c|}
\hline Site & 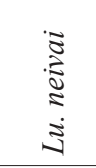 & 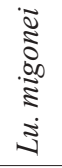 & 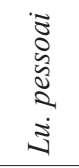 & 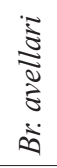 & $\begin{array}{l}\text { Phlebotomine } \\
\text { /night } \pm \text { SD }\end{array}$ & $\begin{array}{l}\text { Lu. neivai } \\
\text { female } \%\end{array}$ & $\begin{array}{c}\text { Lu. neivai } \\
\text { gravid \% }\end{array}$ \\
\hline Periph. neigh. extradomestic & 1583 & 1 & 1 & 0 & $636.0 \pm 88.7$ & $56.1^{\mathrm{a}}$ & 1.4 \\
\hline Periph. neigh. peridomestic & 233 & 1 & 0 & 0 & $78.0 \pm 20.7$ & $65.2^{\mathrm{a}}$ & 3.9 \\
\hline Periph. neigh. shore & 300 & 0 & 0 & 0 & $100.0 \pm 27.2$ & $61.6^{\mathrm{a}}$ & 1.6 \\
\hline Periurb. neigh.peridomestic 1 & 158 & 0 & 0 & 0 & $52.7 \pm 9.2$ & $44.3^{b}$ & 5.7 \\
\hline Periurb. neigh.peridomestic2 & 8 & 0 & 0 & 1 & $2.7 \pm 0.6$ & $*$ & $*$ \\
\hline Periurb. neigh. peridomestic3 & 4 & 0 & 0 & 0 & $1.3 \pm 1.1$ & $*$ & $*$ \\
\hline Rural extradomestic & 432 & 4 & 76 & 6 & $172.7 \pm 55.9$ & $72.2^{c}$ & 14.4 \\
\hline Rural peridomestic & 534 & 21 & 245 & 0 & $266.7 \pm 68.6$ & $86.1^{\mathrm{c}}$ & 4.1 \\
\hline Farm & 0 & 0 & 0 & 0 & 0 & & \\
\hline Total & 3252 & 27 & 322 & 7 & & & \\
\hline
\end{tabular}

Phlebotomine cumulative captures of three consecutive nights by species. Periph. neigh: Epam peripheral neighbourhood; Periurb. neigh.: Florida periurban neighbourhood; Lu. neivai female (\%): female proportion of Lu. neivai (\%); Lu. neivai Gravid \%*: proportion of gravids among females of $L u$. neivai $(\%)$ capture with less than 20 individuals; ${ }^{\text {a,b,c,d,e. }}$ : each letter differed significantly from the other with a $P<0.05$

and epidemiological pattern was the same as in other foci of the country where the parasite characterized was Leishmania (V.) braziliensis (Sosa Estani \& Salomón 2002), although $L$. (V.) guyanensis was reported previously in a single isolated from other site of the province of Corrientes (Marco et al. 2005). This is the southernmost known TL outbreak in Argentina up to now and the first confirmed in the province of Corrientes. The National Surveillance System reported 98 cases for Corrientes in 1982 and 253 cases in 1984, but these figures are assumed as typing errors because the reference center of Corrientes, the Dermatologic Dispensary, recorded only two cases in 1982 and no cases in 1984, and the local university center, Cenpetrop, reported that before 1988 only one or two TL cases were reported each year in the province (Borda et al. 1998a).

The entomological survey captured 3608 phlebotomine and, $90 \%$ of these were identified as $L u$. neivai. This species has adapted to the human modified environments and has been incriminated as the vector during epidemics of $L$. (V.) braziliensis in several Argentinean foci (Salomón 2002, Córdoba Lanús et al. 2006), while the vector during inter-epidemic zoonotic cycles could be $L u$. migonei o Lu. shannoni as suggested for other areas (Alexander \& Maroli 2003, Chavez \& Añez 2004). Phlebotomine captures during the first season of activity of sand flies after the outbreak, was assumed to be representative of the relative abundance distribution during Leishmania transmission, because there were not reported or observed major environmental changes since then up to the study. The greatest species diversity was found in the rural areas with less human intervention, and the highest $L u$. neivai abundance in the peripheral ecotone, distribution described in the peridomestic transmission scenarios of Argentina (Salomon et al. 2001a,b, Salomon et al. 2006b), and other foci of the region where Lu. intermedia (from the same species complex as Lu. neivai) was the incriminated vector (Kawa \& Sabroza 2002, Lemos \& Lima 2005, Dos Santos 2005, Massafera et al. 2005). The relative proportion of females and gravid females suggest breeding sites in the rural secondary vegetation, and potential colonization of peridomestic habitats in surrounding vegetation patches. In the province of Salta, located in Northwestern Argentina, this kind of rural/periurban and extra/peridomestic distribution was associated with a meta-population pattern (Salomon et al. 2004), where a peridomestic sand fly population could be re-colonized from an extradomestic source population after a focal insecticide treatment, or the peridomestic population may lead to the extinction by natural causes. The $L u$. neivai abundance and the proportion of gravid females (potentially infective) could also be thought as risk indicators for increased of TL transmission. The spatial distribution of these indicators in Bella Vista shows a risk gradient associated with the stability, proximity, and size of the vegetation patches. Therefore, the risk is higher in the peripheral ecotone and lower in the periurban sites, which is consistent with the risk factor "to have high vegetation (secondary forest) close to the house" observed in the questionnaires.

However, in order to define the risk distribution in addition to vector abundance, the social use of the space should also be taken into account (Kawa \& Sabroza 2002). Most of the cases reside in the Florida neighbourhood, the area with the highest human density among the areas sampled in search of vectors. On the other hand, at least $50 \%$ of the cases were located in the 'carrizal'-peripherial neighbourhood during the hours of vector activity making clay bricks, walking to and from the farm for the evening-night chores (selection, packaging, track loading), or recollecting 'carrizal' herbs (frost prevention and handicrafts). These abundance-exposure results indicate 
the need to be aware of any changes in the land use and its real estate value in TL endemic areas. The land related changes could increase the human population in sites with high vector density, or push the vector populations to crowded neighbourhoods. In Bella Vista, during the three years prior to the outbreak, abandoned cultures of citrus trees close to the periurban Florida were deforested to be reactivated or reconverted in farms, or to build the peripheral neighbourhood Epam in front of the 'carrizal'.

Finally, in order to examine the TL epidemic, weather variables were integrated with the entomological data and social land use data. During 1998, in the same site identified in this study as 'rural' capture station' $\left(28^{\circ} 27^{\prime} 02^{\prime} \mathrm{LS}, 59^{\circ} 00^{\prime} 03^{\prime \prime} \mathrm{LW}\right)$ a cluster of five cases of TL was reported and two Lu. intermedia sensu lato individuals were captured (Borda et al. 1998b). This report only indicates parasite circulation and the existence of the competent vector at least 5 years before the main epidemic outbreak, but it does not provide any conclusion about the progression of the risk or the phlebotomine abundance. The trend of TL transmission since 1998 was not known because any local based surveillance or diagnostic system was settled in Bella Vista despite the closeness of the cases reported to the city. The actual phlebotomine abundance was not known because the team that reported two sandflies in 1998 captured again in Bella Vista only two Lu. neivai (Borda et al. 2005), during the same period of 2003 that the phlebotomine reported here were collected. However, epidemiological local records confirm that an epidemic outbreak of TL took place during the first semester of 2003 in Bella Vista, and that the transmission peaked one year after an extraordinarily high period of rainfall. The rainfall- $L u$. neivai abundance correlation with a lag of 52 weeks was already reported for the northeastern and northwestern peridomestic foci of Argentina (Salomon et al. 2002, 2004). On the other hand, the river trend and overflow data during the same year of the outbreak could imply an increase in the potential breeding surface of phlebotomine in the 'carrizal' and brick making area. Lastly, the overflow of pools and the draining streams on the edge of the city may cause the migration of wild infected animals to peridomestic periurban habitats. During the phlebotomine captures, many sinanthropic and wild marsupials, edentate and rodents were observed in the backyards of the houses close to the water stream. The inhabitants explained that this 'invasion' happens due to the growing land covered by water from the inland pools. This perception is consistent with the satellite imagery estimates. The high frequency of exposure among cases compare to controls in regards to the factor "to have a stream of water near the house" and the protective factor "to have cats in the house" could be associated with this parasite source related to closeness of potential reservoir to houses and predation on the reservoirs. These are the only risk and protection factors identified among the surveyed factors. Possible confounders or age bias was eliminated by the design, or minimized as the recalling factor (the questionnaires were made at the end of the outbreak).
However, other factors as over-matching (controls were selected in the same block of cases), and the small size of the sample limited the discussion about the risk factors associated with Leishmania infection so should be cautiously interpreted.

Phebotomine captures were also performed with light minitraps CDC like in the northeastern region of province of Corrientes, in a natural reserve $7 \mathrm{~km}$ from Gobernador Agrónomo Valentín Virasoro City, close to the Uruguay river basin $\left(28^{\circ} 02^{\prime} \mathrm{LS}, 56^{\circ} 00^{\prime} \mathrm{LW}\right)$. The sand fly/night captured there from July 2nd to 4th 2003 were 2.5 Lu. shannoni, $1.5 \mathrm{Lu}$. neivai, and $0.5 \mathrm{Lu}$. cortelezzii. Therefore, any generalization of the results of Bella Vista to other scenarios in the area should be assessed previously in each focus (unpublished data)

In conclusion, during the 2003 TL outbreak in Bella Vista, province of Corrientes, the active transmission was possible found in the eastern outskirts of the city and the city border. The risk increased from the periurban neigh-bourhood, Florida, to the marginal ecotone of the Epam neighbourhood. The probability of transmission was associated with the proximity and size of dense patches of secondary vegetation related to human distribution or activities. The potential increase of breeding sites of sand flies, and relocation of vectors and reservoirs due to progressive deforestation, the proximity of the houses to the secondary vegetation, the water streams connected to natural pools cycle, the rainfall of the previous year, and the height of the river during the same year could all have contributed to the outbreak. The confluence of weather, environmental, and cultural factors implies that the epidemic phenomena are not necessarily periodic, and therefore, sporadic human cases should be expected regularly. Furthermore, Bella Vista is located in front of a Ramsar site promoted for ecological and sport fishing tourism, national and international, where populations of $L u$. neivai have been already reported (Salomón et al. 2006a). Although the results indicate that the urban transmission in the southermost foci of TL is still a border-green patch ecotone related problem, it also reinforces the recommendations about the settlement of a local-based system of surveillance, diagnosis and treatment of cases, and the entomological surveillance at sentinel sites. Likewise, TL risk should be assessed for any project that involves time or space changes in land use throughout the endemic area, specifically new neighbourhood building projects that are close to city borders.

\section{ACKNOWLEDGMENTS}

To Susana Bernich de Gómez (Dispensario Dermatolológico "H. Casares de Blaquier"), Tomás Orduna (Hospital Muñiz, Buenos Aires), Sandra Pérez (Dirección Epidemiologia, Ministerio de Salud), Dina Bravo and Horacio Denegri (Hospital Bella Vista), Mario Francisco Haberle and Viviana Marain (Intendencia Bella Vista), Arturo D Carcaño (Estación Experimental Bella Vista, Instituto Nacional Tecnología Agropecuaria), Eulogio Encina and Ramón Sánchez (Subprefectura de Goya, Dto Reforzado Bella Vista, Prefectura Naval Argentina), and the personel of the Coordinación Nacional de Vectores for field and laboratory expert technical assistance. 


\section{REFERENCES}

Alexander B, Maroli M 2003. Control of phlebotomine sand flies. Med Vet Entomol 17: 1-18.

Bejarano EE, Uribe S, Rojas W, Velez ID 2002. Phlebotomine sand flies (Diptera: Psychodidae) associated with the appearance of urban leishmaniasis in the city of Sincelejo, Colombia. Mem Inst Oswaldo Cruz 97: 645-647.

Bejarano JFR, Duret JP 1950. Contribución al conocimiento de los flebótomos argentinos (Diptera, Psychodidae). Rev San Mil Arg 49: 327-336.

Borda EC, Rea MJF, Rosa JR, Mosqueda LA, Gené CM 1998a. Investigaciones sobre leishmaniasis en la provincia de Corrientes. In AC Seijo, OP Larghi, MO Espinosa, M Rivas, M Sabattini (eds), Zoonosis y Enfermedades Emergentes, Asociación Argentina de Zoonosis, Buenos Aires, p. 193198.

Borda CE, Rea MJF, Rosa JR, Mosqueda LA 1998b. Foco de leishmaniasis cutánea y muco-cutánea en Bella Vista, provincia de Corrientes, Argentina. In E Moretti, E Durante de Isola (eds), XVI Reunión Científica Anual, Sociedad Argentina Protozoología y Enfermedades Parasitarias, Carlos Paz, Córdoba, p. 41.

Borda CE, Rea MJF, Rosa JR 2002. Urbanization of the human leishmaniasis in the Northeast of the Argentina. Entomol Vect 9 (Suppl. 1): 56.

Borda CE, Rea MJF, Mosqueda LA 2005. Sand flies in the districts of Corrientes and Bella Vista, Argentina. Arch Inst Past Tunis 82: 102.

Cabrera AL 1976. Regiones fitogeográficas Argentinas. Encicl Arg Agric Jard 2: 1-85.

Campbell-Lendrum D, Dujardin JP, Martínez E, Feliciangeli MD, Pérez JE, Silans LN, Desjeux P 2001. Domestic and peridomestic transmission of American cutaneous leishmaniasis: changing epidemiological patterns present new control opportunities. Mem Inst Oswaldo Cruz 96: 159-162.

Carnevali R 1994. Fitogeografia de la Provincia de Corrientes. Gobierno de la Provincia de Corrientes-INTA, Corrientes, p. 1-324.

Chavez LF, Añez N 2004. Species co-ocurrence and feeding behavior in sand fly transmission of american cutaneous leishmaniasis in Western Venezuela. Acta Trop 92: 219-224.

Córdoba-Lanús E, Lizarralde De Grosso M, Piñero JE, Vakkadares B, Salomón OD 2006. Natural infection of Lutzomyia neivai with Leishmania spp. in Northwestern Argentina. Acta Trop 98: 1-5.

Desjeux P 2001. The increase in risk factors for leishmaniasis worldwide. Trans R Soc Trop Med Hyg 95: 239-243.

Dos Santos GP, Sanavria A, Marzochi MC, dos Santos EG, Silva VL, Pacheco RS, Mouta-Confort E, Espíndola CB, de Souza MB, Ponte CS, da Conceição NF, de Andrade MV 2005. Prevalência de infecção canina em áreas endêmicas de leishmaniose tegumentar americana do município de Paracambi, Estado do Rio de Janeiro, no período entre 1992 e 1993. Rev Soc Bras Med Trop 38: 161-166.

Duret JP 1952. Notas sobre flebótomos argentinos. Rev San Mil Arg 51: 534-536.

Kawa H, Sabroza PCh 2002. Espacialização da leishmaniose tegumentar na cidade do Rio de Janeiro. Cad Saú Públ 18: 853-865.

Lemos JC, Lima SC 2005. Leishmaniose tegumentar americana: flebotomíneos em área de transmissão no Município de Uberlândia, MG. Rev Soc Bras Med Trop 38: 22-26.

Leonardo FS, Rebêlo JM 2004. A periurbanização de Lutzomyia whitmani em área de foco de leishmaniose cutânea, no estado do Maranhão. Brasil. Rev Soc Bras Med Trop 37: 282-284.

Marco JD, Barroso PA, Calvopina M, Kumazawa H, Furuya M, Korenaga M, Cajal SP, Mora MC, Rea MM, Borda CE, Basombrio MA, Taranto NJ, Hashiguchi Y 2005. Species assignation of Leishmania from human and canine american tegumentary leishmaniasis cases by multilocus enzyme electrophoresis in North Argentina. Am J Trop Med Hyg 72: 606-611

Marcondes CB 1996. Redescription of Lutzomyia (Nyssomyia) intermedia (Lutz \& Neiva, 1912), and resurrection of $L$. neivai (Pinto, 1926) (Diptera, Psychodidae, Phlebotominae). Mem Inst Oswaldo Cruz 97: 457-462.

Massafera R, da Silva AM, Carvalho AP, dos Santos DR, Galati EA, Teodoro U 2005. Fauna de flebotomíneos do município de Bandeirantes, no estado do Paraná. Rev Saú Públ 39: 571-577.

Mott KE, Desjeux P, Moncayo A, Ranque P. de Raadt P 1990. Parasitic diseases and urban development. Bull WHO 68: 691-698.

Salomón OD 2002. Leishmaniosis: vectores y brotes epidémicos en Argentina. In OD Salomón, Actualizaciones en Artropodología Sanitaria Argentina, Fundación Mundo Sano, Buenos Aires, p. 185-196.

Salomón OD, Mocarbel NJ, Pedroni E, Colombo J, Sandillú M 2006a. Phlebotominae: vectores de leishmaniasis en las provincias de Santa Fe y Entre Ríos, Argentina. Medicina (Buenos Aires) 66: 220-224.

Salomón OD, Orellano PW, Quintana MG, Pérez S, Sosa Estani S, Acardi S, Lamfri M 2006b. Transmisión de la leishmaniasis tegumentaria en Argentina. Medicina (Buenos Aires) 66: 211-219.

Salomón OD, Rossi GC, Spinelli GR 2002. Ecological aspects of phelobotomine (Diptera, Psychodidae) in an endemic area of tegumentary leishmaniasis in the Northeastern Argentina, 1993-1998. Mem Inst Oswaldo Cruz 97: 163-168.

Salomón OD, Sosa Estani S, Canini L, Córdoba Lanús E 2001a. Leishmaniosis tegumentaria en un área con niveles epidémicos de transmisión, Salta, Argentina, 1998. Medicina (Buenos Aires) 61: 284-290.

Salomón OD, Sosa Estani S, Monzani AS, Studer C 2001b. Brote epidémico de leishmaniosis tegumentaria en Puerto Esperanza, provincia de Misiones, 1998. Medicina (Buenos Aires) 61: 385-390.

Salomon OD, Wilson ML, Munstermann LE, Travi BL 2004. Spatial and temporal patterns of phlebotominae sand flies (Diptera: Psychodidae) in a cutaneous leishmaniaisis focus in Northern Argentina. J Med Entomol 41: 33-39.

Segura EL, Juan N, Piquin AL, Cuba Cuba CA, Abramo Orrego L, McMahon-Pratt D, Montamat EE, Momen H, Grimaldi Jr G 2000. Molecular and biologic characterization of Leishmania parasites implicated in an epidemic outbreak in northwestern Argentina. Parasitol Res 86: 504-508. 
Sosa Estani S, Salomón OD 2002. Aspectos clínicos, epidemiológicos y entomológicos de la transmisión de la leishmaniosis en la República Argentina. Sociedad Iberoamericana de Información Científica (SIIC), Sección Expertos Invitados. http://www.siicsalud.com/main/expinv.htm.

Sosa Estani S, Segura EL, Gómez A, Salomón OD, Peralta M, Coutada V, Medina Ruiz L 2001. Leishmaniose cutânea no Norte da Argentina. Fatores de risco identificados num estudo caso-coorte em três municipios de Salta. Rev Soc Bras Med Trop 34: 511-517.

Sosa Estani S, Segura EL, Salomón OD, Gómez A, Peralta M,
Coutada V 2000. Tegumentary leishmaniasis in Northern Argentina: distribution of infection and disease, in three municipalities of Salta, 1990-1992. Rev Soc Bras Med Trop 33: 573-582.

Spinelli GR, Rossi GC, Rodríguez EA 1999. Further notes on Phlebotominae from Argentina (Diptera: Psychodidae). Rev Soc Ent Arg 58: 197-200.

Young DG, MA Duncan 1994. Guide to the identification and geographic distribution of Lutzomyia sand flies in Mexico, the West Indies, Central and South America (Diptera: Psychodidae). Mem Am Entomol Inst 54: 1-881. 